\title{
Use of Agaricus bisporus mushroom in beef burgers: antioxidant, flavor enhancer and fat replacing potential
}

\author{
Iliani Patinho ${ }^{1}$, Erick Saldaña ${ }^{1,4}$, Miriam Mabel Selani ${ }^{2}$, Adriano Costa de Camargo ${ }^{3}$, Thais Cardoso Merlo ${ }^{1}$, \\ Beatriz Schmidt Menegali ${ }^{1}$, Anna Paula de Souza Silva ${ }^{1}$ and Carmen J. Contreras-Castillo ${ }^{1 *}$
}

\begin{abstract}
This study aimed to evaluate the potential use of Agaricus bisporus mushroom as a natural antioxidant, fat/salt substitute and flavor enhancer in beef burger. Ten treatments were considered using a fractional factorial design (salt [0.5, 1.25 and 2.0\%], fat [10, 15 and 20\%] and mushroom content [0, 15 and 30\%]). Treatments were characterized by instrumental and sensory measurements. The statistical design indicated that fat content had little influence on the results. The principal component analysis showed that the incorporation of mushrooms and salt modified the texture, moisture and water activity. Oxidative stability decreased as the salt content increased, at a low-fat content. Finally, the sensory profile was affected by the mushroom and salt contents, with the fat content exerting the least influence. Therefore, mushroom incorporation in beef burger may be a feasible strategy to reduce the fat content of beef burgers.
\end{abstract}

Keywords: Beef burger, Agaricus bisporus, Lipid oxidation, Texture profile analysis, Descriptive analysis

\section{Introduction}

Because of the population aging, inadequate nutrition and lifestyle-related diseases, health concerns have become increasingly important (Araújo, 2017). The dietary pattern has changed to a diet where meats, fats and simple carbohydrates are widely consumed, while the intake of plant proteins and fibers is dramatically reduced (Kendall et al. 2010). This has contributed to the nutritional transition observed in the last decades, characterized by increased incidence of noncommunicable diseases (NCD), such as metabolic cardiovascular diseases (CVD) and tumors (Ribeiro et al. 2019). NCDs have been pointed as major health challenges of the twenty-first century. In fact, according to a recent reports, in 2016, NCDs were responsible for $71 \%$ (41 million) death worldwide and 17.9 million death were related to CVD, which was followed by cancers (9 million), chronic respiratory diseases (3.8 million), and diabetes (1.6 million death) (Silva et al. 2019; WHO, 2018).

\footnotetext{
* Correspondence: ccastill@usp.br

${ }^{1}$ Departamento de Agroindústria, Alimentos e Nutrição (LAN), Escola Superior de Agricultura "Luiz de Queiroz" (ESALQ), Universidade de São Paulo (USP), Avenida Pádua Dias, 11, Piracicaba, SP 13418-900, Brazil

Full list of author information is available at the end of the article
}

In order to address the above concerns, consumers are looking for products with reduced salt, fat and sugar contents as well as free and/or low in synthetic antioxidants. However, they are not willing to sacrifice the sensory quality of these foods (Tuorila \& Monteleone, 2009). According to Brazil Food Trends 2020 (ITAL, 2010), the niche market for health-conscious consumers has reached $21 \%$ in the Brazilian society and has a strong potential for growth. However, producing foods with a balanced nutritional profile preserving the sensory quality is challenging.

In order to overcome this technological limitation, different strategies have been explored to reduce the fat/ salt content and the use of synthetic antioxidants, and, at the same time, to preserve the sensory quality of the products. However, to date, most of the alternatives studied negatively affected the sensory properties of the product. de Camargo and Schwember (2019) summarized the phenolic-driven sensory changes in different food systems. According to these authors, the sensory quality of the final product containing phenolic compounds must be considered. Likewise, fat replacement may induce negative sensory changes. For example, 
Saldaña et al. (2018) manufactured a bologna sausage added with healthy fats, but consumers rejected the product based on their texture sensory properties. In another study, Selani et al. (2011) incorporated grape seed and peel extracts as natural antioxidants in chicken burger and observed that the color of the product was affected. Almeida et al. (2016) noticed bitter and metallic residual taste in salami manufactured with $\mathrm{NaCl}$ replacement by $\mathrm{KCl}$ and $\mathrm{CaCl}_{2}$.

In this context, the incorporation of plant-based products into animal origin foods has been highlighted because of their nutritional profile (e.g., no cholesterol, low fat ingredients) (Reis et al. 2017). In addition to plants, mushrooms have also emerged as raw materials to be studied and applied in food industries (Sánchez, 2017).

Among various edible species, $A$. bisporus is the most produced and consumed mushroom in Brazil (ANPC, 2013; Chang, 1999). In particular, A. bisporus is popular in the global food market, accounting for $15 \%$ of total worldwide mushroom production (Ramos et al. 2019). Mushrooms have a high percentage of easily digestible protein and present a meat-like texture (de Jesus, 2015), which make them an interesting choice for the replacement of animal proteins. They also contain flavor enhancers (Phat et al. 2016), considerable fiber content (Manzi et al. 2001), and a high antioxidant activity (Barros et al. 2008) which demonstrates their potential for application in different foods.

It is worth mentioning that the use of mushrooms as a substitute for animal protein or fat provides a sustainable food supply to the population, as it encourages the reduction of meat consumption. Rearing of animals for meat production is often associated with environmental strain due to emission of greenhouse gases and water pollution (streams and rivers), as well as rampant deforestation for the expansion of livestock farms that has all put additional pressure on natural resources (Aiking, 2011; Steinfeld et al. 2006). In addition, mushroom production uses agroindustrial residues as substrates (crushed corn cobs, cottonseed peels, soybean hulls, peanut hulls and cocoa husks) (Sánchez, 2010) providing a useful solution for byproducts that previously presented management, treatment and disposal challenges.

Recent studies have evaluated the incorporation of mushrooms in meat-based foods aiming to reduce sodium content (Mattar et al. 2018) and lipid oxidation (Tom et al. 2018) and to replace fat (Wong, 2017). However, it is still unclear in which of these strategies $A$. bisporus presents greater potential for development of a healthier burger. Regardless of the strategy to be used, the consumer will demand a product with sensory quality comparable to that of a conventional product. Thus, determining the sensory profile of the product is very important, since they are the main drivers of liking
(Selani et al. 2016). The sensory profile of foods is commonly explored through descriptive analysis (DA), which makes it possible to quantitatively determine the effect of any change in the formulation (Lawless \& Heymann, 2010).

In this context, the study aimed to assess different strategies of beef burger reformulation (fat/salt reduction, addition of natural antioxidants) through the addition of $A$. bisporus considering instrumental and sensory properties.

\section{Materials and methods Materials}

Mushrooms were supplied by Zucca Cogumelos (Salto / SP, Brazil), seasonings and other additives (black pepper, onion, garlic, sodium erythorbate, sodium tripolyphosphate and monosodium glutamate) were supplied by Ibrac (Rio Claro / SP, Brazil). The beef was supplied by the VPJ Alimentos (Pirassununga / SP, Brazil). Pork back fat was purchased in the local commerce (Piracicaba / SP, Brazil).

\section{Conditioning of mushrooms}

Mushrooms were prepared following the recommendations of $\mathrm{Ng}$ and Tan (2017). Firstly, mushrooms were washed and $100 \mathrm{~g}$ portions were added with $100 \mathrm{~mL}$ of distilled water and submitted to heating in a microwave oven (800 W) (ME21S, Electrolux, Manaus, Brazil) for $1.5 \mathrm{~min}$ in an open vessel. After filtration of the solution in sieves, the filtrate was discarded and the mushroom was ground for 30s using a mini-processor (HC32, X.J. Eletrics, Shenzhen, China). The ground mushroom was the material added to the burger formulation.

Since one objective of the study was to evaluate the antioxidant potential of $A$. bisporus after filtration of the cooked mushrooms, they were again filtered (under vacuum) and the obtained filtrate, called mushroom extract, was stored in an amber bottle at $18^{\circ} \mathrm{C}$ for total phenolic content and antioxidant activity measurements.

\section{Total phenolic content and antioxidant activity}

The total phenolic content was determined using the Folin-Ciocalteau reagent, as described by Al-Duais et al. (2009), with some modifications. The results were expressed as mg gallic acid equivalent (GAE)/g sample. The antioxidant activity was measured using the DPPH assay (Al-Duais et al. 2009) with modifications and the ABTS and ORAC assays were determined according to Melo et al. (2015). In all three methods, Trolox was used as standard and the results were expressed as $\mu \mathrm{mol}$ Trolox equivalent/g sample. The FRAP method was performed according to Muller et al. (2010) with some modifications and results were expressed as $\mu \mathrm{mol}$ of 
ferrous sulphate equivalent/g of sample ( $\mu \mathrm{mol} \mathrm{FS/g).} \mathrm{All}$ determinations were performed in triplicate.

\section{Preparation of burgers}

Nine beef burger formulations were prepared following a fractional factorial design $3^{3-1}$. The main aim was to study three factors (salt, fat and mushroom concentrations) in three levels each. Additionally, a control treatment was developed containing similar fat and salt contents compared to those of commercial beef burgers. The minimum and maximum levels of each factor were based on previous studies (Lemos, 2009) and laboratory pre-tests.

The beef and the pork back fat were ground in a grinder (P33003, Hermann SA) using a 5 and $3 \mathrm{~mm}$ disc, respectively. After grinding, the ingredients were mixed manually for $10 \mathrm{~min}$ in the following order: beef $(40,55$ and $70 \%), \mathrm{NaCl}(0.5,1.25$ and $2.0 \%$ ), water $(\mathrm{min} 6.9 \%$ and max. $18.4 \%)$, sodium erythrobate $(0.05 \%)$, monosodium glutamate $(0.05 \%)$, mushroom $(0,15$ and $30 \%)$, black pepper $(0.05 \%)$, garlic powder $(0.3 \%)$, onion powder $(0.3 \%)$, sodium tripolyphosphate $(0.3 \%)$ and pork back fat (10, 15 and 20\%). After obtaining the meat batter, $100 \mathrm{~g}$ portions were weighed, shaped $(10 \mathrm{~cm}$ diameter and $1 \mathrm{~cm}$ thick) and the burgers were vacuum packed and stored at $-18{ }^{\circ} \mathrm{C}$. For the determination of lipid oxidation, samples were stored for 16 days in a cooling chamber $\left(2^{\circ} \mathrm{C}\right)$ with white fluorescent light and then evaluated.

\section{Physicochemical analysis of burgers Sodium content}

The sodium content of beef burgers was determined as described by AOAC (1996). Five grams of each dried and lyophilized sample were converted to ash in a muffle furnace at $550{ }^{\circ} \mathrm{C}$ for $6 \mathrm{~h}$. Subsequently, the ashes were cooled to room temperature, solubilized in $2.5 \mathrm{~mL}$ of a $1: 1 \mathrm{v} / \mathrm{v}$ solution containing nitric acid and hydrochloric acid and transferred to a $50 \mathrm{~mL}$ volumetric flask. A blank sample was used as a control. The readings were performed in a flame photometer (B462, Micronal, Series 40707, Pirassununga, Brazil), considering three replicates.

\section{Moisture content and water activity}

Moisture was determined in raw samples following the AOAC (2000). Water activity $\left(a_{w}\right)$ at $25^{\circ} \mathrm{C}$ was determined on cooked samples using AquaLab equipment (4TE, Decagon Devices, Pullman, USA). Both determinations were performed in triplicate.

\section{$\mathrm{pH}$ determination}

The $\mathrm{pH}$ was determined directly on the raw burger, using a pH meter (Oakton pH 300 series 35618, Vernon
Hills, Illinois, USA) equipped with a glass electrode. The analysis was performed in triplicate using three burgers for all treatments.

\section{Instrumental color measurement}

Color measurement of burgers was determined using a Konica Minolta colorimeter (Chroma Meter, CR-400, Mahwah, NJ, USA) at $10^{\circ}$ angle, measuring area of $8 \mathrm{~mm}$ in diameter and D65 illuminating source. L * (lightness), $\mathrm{a}$ * (red-green) and $\mathrm{b} *$ (yellow-blue) color coordinates were analyzed. The analysis was performed in triplicate using three burgers for all treatments.

\section{Determination of thiobarbituric acid reactive substances (TBARS)}

TBARS were determined in triplicate according to AOCS (1990), with modifications. The analysis was performed in samples after 16 days of storage, in a white fluorescent light cooling chamber, which simulates real retail conditions. The results were calculated from a standard curve of 1,1,3,3-tetraethoxypropane (TEP) and expressed as $\mathrm{mg}$ of malonaldehyde (MDA) per $\mathrm{kg}$ of sample.

\section{Texture profile analysis (TPA)}

Prior to TPA, the samples were cooked using an electric plate at $150^{\circ} \mathrm{C}$ until the internal temperature reached $75^{\circ} \mathrm{C}$ and then the burgers were cooled to room temperature. The TPA was performed in a TA-XT texturometer (Stable Micro Systems, Godalming, UK) based on the parameters defined by Selani et al. (2016). Three cylinders $(2.5 \mathrm{~cm}$ diameter $)$ per treatment were compressed at $75 \%$ of their original height with the P-35 probe (long axis, regular base) at a speed of $3.3 \mathrm{~mm} / \mathrm{s}$. Hardness, cohesiveness, chewiness and springiness were calculated Saldaña et al. (2015) considering three independent measurements.

\section{Descriptive sensory analysis}

Descriptive sensory analysis (DA) was performed in 14 sessions, following the recommendations proposed by Saldaña et al. (2019). Data collection was performed in the Compusense Cloud software (Compusense Inc., Guelph, Ont., Canada). All participants signed the free and informed consent form that was approved by the ethics committee (CAAE: 98168118.4.0000.5395).

\section{Recruiting}

In the first session, the respondents were recruited using social network advertisements. The candidates, students of the Escola Superior de Agricultura "Luiz de Queiroz", Universidade de São Paulo (ESALQ/ USP), with experience in descriptive analysis, completed a form containing sociodemographic information, frequency 
of consumption of burger and health status. The criteria for participating in DA were: good health, frequent consumption of beef burger and time to participate in all stages of the DA.

\section{Screening}

From the second to the seventh session, the participants' sensory acuity was evaluated in distinguishing basic tastes (sweet, bitter, sour, salty and umami), in recognizing and memorizing odors (coffee, clove, black pepper, onion, garlic and cinnamon) and in the discriminant capacity using four triangle tests, considering the threshold of $25 \%$ error per candidate. In total, 11 candidates ( $90 \%$ women and $10 \%$ men) aged $19-30$ years were selected, with $80 \%$ correct answers for basic tastes, $66.7 \%$ for odors and $75 \%$ for discrimination tests.

\section{Vocabulary development}

A list consisting of 14 descriptors were selected based on our previous works (Rios-Mera et al. 2019; Selani et al. 2016). In addition, there was an optional space that could be used to include an attribute that was not on the list. Candidates received cooked burgers (as described in the TPA method) and were asked to select all the sensory attributes that characterize burgers. At the eighth session, participants defined the final list of sensory attributes, their definition, assessment technique and reference samples, considering the lower and upper end of the scale. Thus, the evaluation form containing the 10 descriptors generated and a 9-cm unstructured linear scale anchored at the extremes with none/weak (left) and strong (right) was elaborated.

\section{Training}

The training was carried out in the ninth and tenth sessions, in which the assessors learned how to use the scales. At the beginning of each session, the assessors tested the references to fix the anchors of each sensory attribute. Then, each assessor received $10 \mathrm{~g}$ of each sample, served monadically and identified with random three-digit numbers, following a Williams's Latin Square design. Water and biscuit were given to clean the palate between samples. The assessors were not required to consume the entire sample, but it was advised that they should standardize the quantity used in each evaluation.

\section{Panel performance}

In the eleventh and twelfth sessions the panel and individual performance was measured by discrimination, repeatability and agreement using the MAM-CAP method (Peltier et al. 2014), which is a synthetic table known as Control of Assessor Performances (CAP) (Schlich, 1997), based on the Mixed Assessor Model (MAM) (Brockhoff et al. 2015).
In the MAM-CAP table (Table 5), each row corresponds to an attribute, each cell reproduces the performance with a "light pink/green" color code, where light pink represents a poor performance and green corresponds to a good performance. The left part of the table shows the panel performance, in which the first column contains the average for each attribute. The next three columns represent discrimination, use of scale and agreement. Then, the root mean squares of error (RMSE) indicates the repeatability. The attributes are classified from the most discriminative to the least discriminative. The right side of the table refers to the individual performance. For each attribute and each assessor, the cell contains indication on discrimination, agreement, use of scale and repeatability. The discrimination is indicated by the number of dashes in the cell (from zero to three) according to the $p$-value of the MAM, that is, the more dashes the more discriminating the assessor is.

However, if the assessor is not discriminant, the consensus with the team will not be tested and then the cell's color will be grey. Finally, less repeatable raters are identified with the letters "lr" (less repeatable) according to the RMSE. For each attribute, the assessors are classified as decreasing the discriminant capacity (Peltier et al. 2014).

\section{Final assessment}

In the thirteenth and fourteenth sessions, the final evaluation (10 samples per session) was performed using the vocabulary developed by the trained panel, following the same procedure applied in the training step.

\section{Experimental design and data analysis \\ Fractional factorial design}

The $3^{3-1}$ fractional factorial design was created using Statistica 12.0 software (StatSoft INC., USA). The construction of the $3^{3-1}$ design starts by defining the two factors: Fat (A) and Salt (B). The Mushroom (C) factor was constructed from the interaction of the first two factors. Factor $\mathrm{C}$ levels were calculated as $\mathrm{C}=3-\bmod 3$ $(A+B)$. The interactions of the factors were calculated by the expression: $0=\bmod 3(A+B+C)$. The parameters of the ANOVA model were estimated; then, the significance of the linear and quadratic effect of each factor could be calculated.

\section{Instrumental measurements}

Differences in mean values of the instrumental properties of the burger samples were analyzed through oneway analysis of variances (ANOVA). The means were compared using the Tukey test at 95\% confidence. Principal Component Analysis (PCA) was performed on the correlation matrix of instrumental results. 


\section{Sensory analysis}

The panel performance was evaluated through the MAM-CAP method, which unfolds the agreement of the panel on (1) the use of the scale and (2) pure disagreement. The MAM model is presented in eq. 1.

$$
Y_{i j k}=\mu+\alpha_{i}+\gamma_{j}+\beta_{i} x_{j}+d_{i j}+\varepsilon_{i j k}
$$

Where $Y_{i j k}$ is the intensity of the sensory attribute considering the response of the assessor $i$ to the attribute $j$ in $k$ repetition. The effect of the assessor was represented by the factor $\alpha_{i}, \gamma_{j}$ is the effect of the product, $\beta_{i} x_{j}$ is the coefficient related to the use of scale and $d_{i j}$ is related to pure disagreement, where $\beta_{\mathrm{i}}$ is the coefficient by which it is necessary to multiply the deviations of the panel to be as close as possible to the deviation of the assessor. This coefficient is obtained by linear regression. Thus, the term $\beta i x j$ corresponds to the disagreement related to a different use of the scale. The pure disagreement represents the disagreement without the scale effect. The MAM-CAP uses the pure disagreement in the calculation of the significance of the products in the ANOVA model, enhancing the discrimination power of the product (Peltier et al. 2014).

In the final assessment, the MAM model was also used, followed by the Tukey test at $95 \%$ confidence. In order to obtain a synthetic view of the sensory profile, a multivariate analysis of variance (MANOVA) was performed, followed by the Canonical Variate Analysis (CVA) based on MAM, called MAM-CVA (Merlo et al. 2018; Peltier et al. 2018). The MAM-CVA builds a sensory map, considering the multivariate discriminative capacity, later expressed in the size of the confidence ellipses around the samples (Peltier et al. 2018). This confidence ellipses can be interpreted as follows: (1) when two ellipses of the samples are not superimposed, the two centroids of the product are significantly different; (2) when the ellipses are superimposed, the two centroids of the sample are similar. Sensory statistical analyzes were performed using the TimeSense software (INRA, TSI, Dijon, France).

\section{Results and discussion}

\section{Total phenolic content and antioxidant activity}

According to Table 1, A. bisporus mushroom extract presented a phenolic content of $0.64 \mathrm{mg} \mathrm{GAE} / \mathrm{g}$. Ng and Tan (2017) used the same method and cooking parameters of this study but found lower values in $A$. bisporus mushroom $(0.25 \mathrm{mg} \mathrm{GAE} / \mathrm{g})$. This fact may be related to the use of cooking water to obtain the extract, making it more diluted compared to the present study.

Recently, some methodological problems in colorimetric measurement have been reported, which may jeopardize the accurate determination of the antioxidant capacity of
Table 1 Total phenolic content and antioxidant activity of $A$. bisporus mushroom extract

\begin{tabular}{ll}
\hline Method & Extract of mushroom \\
\hline Total phenolic content (mg GAE/g) & $0.64 \pm 0.04$ \\
DPPH ( $\mu \mathrm{mol}$ Trolox/g equivalents) & $8.46 \pm 0.17$ \\
ABTS ( $\mu \mathrm{mol}$ Trolox/g equivalents) & $1.06 \pm 0.08$ \\
ORAC ( $\mu \mathrm{mol}$ Trolox/g equivalents) & $64.51 \pm 5.31$ \\
FRAP ( $\mu$ mol FS/g equivalents) & $4.21 \pm 0.21$ \\
\hline
\end{tabular}

Results are means \pm standard deviation in triplicate

the product. In this sense, different phenolic compounds have been mentioned to explain the antioxidant capacity of plant foods, their processing by-products as well as novel molecules in different food model systems (de Camargo et al. 2017a; Perera et al. 2018; Shahidi \& Hossain, 2018). According to Liu et al. (2013), the main phenolic compounds of $A$. bisporus, on a dry weight basis, are myricetin $(2729.46 \mu \mathrm{g} / \mathrm{g})$, followed by caffeic acid (392.51) and gallic acid $(280.45 \mu \mathrm{g} / \mathrm{g})$ while lower concentrations of protocatechuic acid $(83.26 \mu \mathrm{g} / \mathrm{g})$, catechin $(56.74 \mu \mathrm{g} / \mathrm{g})$ and ferulic acid $(42.83 \mu \mathrm{g} / \mathrm{g})$ were also quantified by ultra-high performance liquid chromatography-tandem mass spectrometry (UHPLC-MS). Hyphenated techniques, such LCMS have a critical role on identification and quantification of polyphenols (de Camargo et al. 2018; Granato et al. 2018). Gąsecka et al. (2018) evaluated the phenolic acid profile of seven strains of $A$. bisporus, thus lending support to the data reported by Liu et al. (2013).

The phenolic content found in the mushroom extract obtained in the current work is lower than the values reported by Dubost et al. (2007) (8.00-10.65 mg GAE/g) and Palacios et al. (2011) (3.4 mg GAE/g). However, in these previous studies, phenolic compounds were extracted from lyophilized mushrooms (more concentrated in phenolics than fresh ones), milled into small particles (greater surface area for the solvent to penetrate, for cell rupture and mass transfer), using different solvents, such as ethanol and methanol. In addition, according to Kita et al. (2013), low values reported here may be associated to the leaching of the soluble phenols that are transferred to the cooking water, as well as to the structural changes of the phenolic compounds during the thermal processing.

Several reports demonstrated that phenolic compounds are found in the soluble (free, esterified, and etherified) as well as in the insoluble-bound forms. The latter fraction is linked to the cell walls of plant materials (Chandrasekara \& Shahidi, 2011; de Camargo et al. 2017b). The present study employed cooked mushroom as ingredient of beef burgers. Because insoluble-bound phenolics must be released from the insoluble-bound form by alkali and/or enzyme treatment (de Camargo et al. 2016), which is not the case here, the contribution of 
insoluble-bound phenolics from mushroom to the antioxidant stability of beef burger is likely negligible or inexistent. However, it is important to mention that, due to probable contribution of insoluble-bound phenolics in the final product (beef burger containing mushroom), our new formulation may offer additional health benefits to final consumers because of potential release upon colonic fermentation (Shahidi \& Peng, 2018; Shahidi et al. 2019).

Regarding the antioxidant activity, the ABTS result $(8.46 \mu \mathrm{mol} \mathrm{TE} / \mathrm{g})$ was higher than the value obtained by $\mathrm{Ng}$ and Tan (2017) $(0.78 \mu \mathrm{mol} \mathrm{TE} / \mathrm{g})$ and lower than the result reported by Bach et al. (2019) $(74 \mu \mathrm{mol} \mathrm{TE} / \mathrm{g})$. Mushroom extract presented a free radical scavenging activity (DPPH) of $1.06 \mu \mathrm{mol} \mathrm{TE} / \mathrm{g}$, which is similar to the result found by $\mathrm{Ng}$ and Tan (2017) $-0.82 \mu \mathrm{mol} \mathrm{TE} /$ g. Regarding the ORAC data, the mushroom extract had a value of $64.51 \mu \mathrm{mol} \mathrm{TE} / \mathrm{g}$. Dubost et al. (2007) evaluated varieties of $A$. bisporus (var. white button, crimini and portobello) and found higher values ranging from 86.33 to $138.33 \mu \mathrm{mol} \mathrm{TE} / \mathrm{g}$. According to Table 1 , the mushroom extract presented $4.21 \mu \mathrm{mol} \mathrm{FS/g}$ for FRAP, which is higher than the value reported by $\mathrm{Ng}$ and Tan (2017) $(2.3 \mu \mathrm{mol} \mathrm{FS/g})$.

Since phenolic compounds are one of the main bioactive compounds responsible for the antioxidant activity, experimental conditions that affect their extraction, such as solute:solvent ratio, previous treatment applied to the raw material (drying, grinding), solvent and method of extraction, method of analysis, among others, influence the antioxidant activity of the samples. In addition, the difference between the results observed in the literature can be explained by variations in maturity, variety, cultural practices, geographical origin, growth stage and sampling conditions (Kim et al. 2003).

\section{Fractional factorial analysis}

Table 2 shows the F-value for each factor studied herein. Overall, mushroom content influenced almost all responses but not springiness. The $\mathrm{NaCl}$ content of the formulations was the second most important factor. Finally, the fat content had no effect on attributes related to appearance and texture. This result indicates the potential addition of mushroom as a fat substitute.

\section{Physicochemical analysis}

Burgers with different concentrations of $\mathrm{NaCl}(0.5,1.25$ and $2.0 \%$ ) were prepared. The treatments with $0.5 \%$ $\mathrm{NaCl}$ presented the lowest sodium content $(0.88,0.91$ and $0.99 \mathrm{~g} / 100 \mathrm{~g}$ dry basis) equivalent to $<300 \mathrm{mg} / 100 \mathrm{~g}$ wet basis. The treatments manufactured with $1.25 \%$ $\mathrm{NaCl}$ had an intermediate sodium content $(1.84,1.86$ and $1.74 \mathrm{~g} / 100 \mathrm{~g}$ ), equivalent to $<600 \mathrm{mg} / 100 \mathrm{~g}$ wet basis. Finally, the highest sodium content was observed in the
Table 2 Variables and F-value for each factor in the fractional factorial design

\begin{tabular}{llll}
\hline Variables & \multicolumn{2}{l}{ F-value } & \\
\cline { 2 - 4 } & Mushroom & Salt & Fat \\
\hline Moisture & $\mathbf{3 3 1 . 0 5 3}$ & $\mathbf{3 6 . 2 8 1}$ & $\mathbf{6 3 9 . 4 2 8}$ \\
Water activity & $\mathbf{8 . 2 7 2}$ & $\mathbf{2 4 7 . 7 1 8}$ & $\mathbf{7 . 6 3 6}$ \\
$\mathrm{pH}$ & $\mathbf{9 . 1 9 6}$ & 1.861 & $\mathbf{8 . 4 2 0}$ \\
$\mathrm{L}^{*}$ & $\mathbf{3 . 7 3 5}$ & 1.456 & 2.416 \\
$\mathrm{a}^{*}$ & $\mathbf{1 1 . 3 8 9}$ & $\mathbf{1 5 . 6 0 4}$ & 1.007 \\
$\mathrm{~b}^{*}$ & $\mathbf{1 0 . 9 4 6}$ & $\mathbf{7 . 1 4 3}$ & 1.289 \\
Hardness & $\mathbf{1 4 3 . 0 7 2}$ & $\mathbf{5 9 . 8 6 0}$ & $\mathbf{1 2 . 0 1 0}$ \\
Springiness & 1.029 & $\mathbf{4 . 6 1 7}$ & 0.001 \\
Cohesiveness & $\mathbf{4 . 9 8 2}$ & 2.656 & 3.287 \\
Chewiness & $\mathbf{3 7 . 0 3 1}$ & $\mathbf{2 5 . 2 8 6}$ & 1.269 \\
Malonaldehyde & $\mathbf{8 . 8 3 2}$ & $\mathbf{5 . 9 9 7}$ & 2.262 \\
equivalents/kg & & & \\
\hline
\end{tabular}

Color in the $L^{*}, a^{*}$ and $b^{*}$ coordinates. $L^{*}\left(\right.$ lightness), $a^{*}$ (red-green) and $b^{*}$ (yellow-blue)

The factors which have a significant effect on responses are marked in bold text and indicate significant differences $(P<0.05)$

treatments manufactured with $2.0 \% \mathrm{NaCl}(<756 \mathrm{mg} / 100$ $\mathrm{g}$ wet basis). In Brazil, the average sodium content of commercial beef burgers is $701 \mathrm{mg} / 100 \mathrm{~g}$ of product (ANVISA, 2012). Accordingly, only treatment G2S3C1 and the control burger exceeded this limit.

The different sodium contents did not affect the $\mathrm{pH}$, color parameters and moisture. However, no significant differences were found in TBARS values in burgers manufactured with low sodium concentrations with or without addition of $A$. bisporus. Moreover, the higher $\mathrm{NaCl}$ content $(2.0 \%)$ and the use of antioxidant substances (mushroom) at intermediate and high level (G1S3C2 and $\mathrm{G} 3 \mathrm{~S} 3 \mathrm{C} 3$ ) decreased the lipid oxidation (Huber, 2012). According to Alnoumani et al. (2017), the inhibition of lipid oxidation in chilled cooked ground beef added with $1 \%$ of $A$. bisporus mushroom powder and with 1.0 and $1.5 \% \mathrm{NaCl}$ is associated to the synergistic effect of both compounds (mushroom powder and $\mathrm{NaCl}$ ), which possibly altered the meat components, facilitating the antioxidant activity.

The moisture content and water activity showed significant differences between the formulations (Table 3). Treatments with $30 \%$ of mushrooms presented higher moisture content, which is related to the fact that $A$. bisporus presents a high moisture content (>90\%) (Bach, 2017; Chang, 2008; Mattila et al. 2001; Pauli, 2010; Reis et al. 2012). Wan Rosli and Solihah (2012) and Cha et al. (2014) reported similar results in ground beef and pork burger, respectively. The formulations G1S1C1, G2S1C3 and $\mathrm{G} 3 \mathrm{~S} 1 \mathrm{C} 2$, which have the lowest $\mathrm{NaCl}$ content $(0.5 \%)$, presented the highest water activity. This may have occurred because the presence of $\mathrm{NaCl}$ in food 
Table 3 Sodium, moisture, water activity, $\mathrm{pH}$, color and TBARS of the 10 burger formulations

\begin{tabular}{|c|c|c|c|c|c|c|c|c|}
\hline Treatments & $\begin{array}{l}\text { Sodium (g/ } \\
100 \mathrm{~g})\end{array}$ & $\begin{array}{l}\text { Moisture (g/ } \\
100 \mathrm{~g})\end{array}$ & $A_{w}$ & $\mathrm{pH}$ & $L^{*}$ & $a^{*}$ & $b^{*}$ & $\begin{array}{l}\text { TBARS (malonaldehyde/kg } \\
\text { equivalents) }\end{array}$ \\
\hline$\overline{G 1 S 1 C 1}$ & $0.99 \pm 0.02^{9}$ & $72.8 \pm 0.54^{\mathrm{cd}}$ & $0.99 \pm 0.00^{\mathrm{ab}}$ & $6.04 \pm 0.03^{\text {cd }}$ & $47.4 \pm 2.29^{a}$ & $17.7 \pm 2.02^{a}$ & $11.3 \pm 1.69^{c}$ & $0.16 \pm 0.00^{b c}$ \\
\hline G1S2C3 & $1.84 \pm 0.01^{e}$ & $77.7 \pm 0.51^{\mathrm{a}}$ & $0.98 \pm 0.00^{b}$ & $6.07 \pm 0.02^{c d}$ & $49.7 \pm 2.68^{\mathrm{a}}$ & $13.9 \pm 1.42^{\mathrm{bc}}$ & $14.8 \pm 1.70^{\mathrm{ab}}$ & $0.42 \pm 0.03^{\mathrm{ab}}$ \\
\hline $\mathrm{G} 1 \mathrm{~S} 3 \mathrm{C} 2$ & $2.63 \pm 0.04^{a}$ & $73.8 \pm 0.43^{b c}$ & $0.98 \pm 0.00^{\mathrm{de}}$ & $6.05 \pm 0.01^{c d}$ & $49.0 \pm 3.35^{a}$ & $13.6 \pm 2.22^{\mathrm{bc}}$ & $14.3 \pm 2.20^{\mathrm{abc}}$ & $0.11 \pm 0.04^{c}$ \\
\hline $\mathrm{G} 2 \mathrm{~S} 1 \mathrm{C} 3$ & $0.91 \pm 0.02^{g h}$ & $74.8 \pm 0.12^{b}$ & $0.99 \pm 0.00^{\mathrm{a}}$ & $6.26 \pm 0.04^{\mathrm{a}}$ & $49.8 \pm 3.95^{\mathrm{a}}$ & $15.7 \pm 1.91^{\mathrm{ab}}$ & $13.0 \pm 1.56^{\mathrm{abc}}$ & $0.21 \pm 0.00^{b c}$ \\
\hline $\mathrm{G} 2 \mathrm{~S} 2 \mathrm{C} 2$ & $1.86 \pm 0.06^{\mathrm{e}}$ & $72.3 \pm 0.41^{d}$ & $0.98 \pm 0.00^{c}$ & $6.18 \pm 0.14^{\mathrm{abc}}$ & $48.9 \pm 3.33^{\mathrm{a}}$ & $15.1 \pm 1.80^{\mathrm{ab}}$ & $14.3 \pm 1.26^{\mathrm{abc}}$ & $0.41 \pm 0.06^{\mathrm{ab}}$ \\
\hline $\mathrm{G} 2 \mathrm{~S} 3 \mathrm{C} 1$ & $2.30 \pm 0.02^{c}$ & $68.3 \pm 0.54^{e}$ & $0.97 \pm 0.00^{\mathrm{e}}$ & $6.02 \pm 0.02^{d}$ & $49.5 \pm 2.38^{a}$ & $14.7 \pm 2.49^{\mathrm{ab}}$ & $12.3 \pm 2.24^{b c}$ & $0.54 \pm 0.00^{a}$ \\
\hline G3S1C2 & $0.88 \pm 0.01^{\mathrm{h}}$ & $68.4 \pm 0.25^{e}$ & $0.99 \pm 0.00^{\mathrm{ab}}$ & $6.14 \pm 0.03^{\mathrm{abcd}}$ & $52.5 \pm 2.31^{a}$ & $15.5 \pm 2.29^{a b}$ & $13.2 \pm 1.78^{\mathrm{abc}}$ & $0.24 \pm 0.18^{b c}$ \\
\hline $\mathrm{G} 3 \mathrm{~S} 2 \mathrm{C} 1$ & $1.74 \pm 0.04^{f}$ & $65.5 \pm 0.41^{f}$ & $0.98 \pm 0.00^{c d}$ & $6.11 \pm 0.02^{\mathrm{bcd}}$ & $47.3 \pm 4.01^{a}$ & $16.7 \pm 2.16^{\mathrm{ab}}$ & $13.3 \pm 1.88^{\mathrm{abc}}$ & $0.28 \pm 0.00^{\mathrm{abc}}$ \\
\hline $\mathrm{G} 3 \mathrm{~S} 3 \mathrm{C} 3$ & $2.41 \pm 0.05^{\mathrm{b}}$ & $69.3 \pm 0.56^{\mathrm{e}}$ & $0.97 \pm 0.00^{\mathrm{e}}$ & $6.21 \pm 0.02^{\mathrm{ab}}$ & $52.9 \pm 3.91^{\mathrm{a}}$ & $11.0 \pm 1.60^{c}$ & $15.5 \pm 1.49^{\mathrm{a}}$ & $0.17 \pm 0.07^{b c}$ \\
\hline Eontrol & $2.13 \pm 0.04^{d}$ & $64.5 \pm 0.79^{f}$ & $0.97 \pm 0.00^{\mathrm{e}}$ & $6.05 \pm 0.03^{c d}$ & $50.2 \pm 3.28^{\mathrm{a}}$ & $13.7 \pm 1.92^{\mathrm{bc}}$ & $12.6 \pm 1.90^{\mathrm{abc}}$ & $0.37 \pm 0.03^{\mathrm{abc}}$ \\
\hline
\end{tabular}

Results are means \pm standard deviation. Means followed of letters different $(\mathrm{a}-\mathrm{g})$ the same column are significantly different $(P<0,05)$. G1S1C1 $=0 \%$ mushroom $0,5 \%$ salt, $10 \%$ fat; G1S2C3 $=30 \%$ mushroom, $1,25 \%$ salt, $10 \%$ fat; G1S3C2 $=15 \%$ mushroom, $2 \%$ salt, $10 \%$ fat; G2S1C3 $=30 \%$ mushroom, $0,5 \%$ salt, $15 \%$ fat; G2S2C2 = 15\% mushroom, 1,25\% salt, $15 \%$ fat; G2S3C1 = 0\% mushroom, 2\% salt, $15 \%$ fat; G3S1C2 $=15 \%$ mushroom, $0,5 \%$ salt, $20 \%$ fat; $G 3 S 2 C 1=0 \%$ mushroom, $1,25 \%$ salt, $20 \%$ fat; G3S3C3 $=30 \%$ mushroom, 2\% salt, 20\% fat; Control $=0 \%$ mushroom, 2\% salt, 20\% fat. Color in the L*, a* and b* coordinates. L*(lightness), a* (red-green) and $\mathrm{b}^{*}$ (yellow-blue)

promotes the diffusion process $-\mathrm{NaCl}$ absorption and loss of water - resulting in the reduction of water activity.

According to Table 3, the $\mathrm{pH}$ values in the raw product varied significantly between the formulations. The presence of 30\% mushroom (G2S1C3 and G3S3C3) slightly increased the $\mathrm{pH}$ of the burger, since the $\mathrm{pH}$ of the cooked A. bisporus mushroom is 6.6. Previous studies have found similar results in beef (Bao et al. 2008) and processed meat product (Choe et al. 2018).

No significant effect on lightness was observed, corroborating the results obtained by Wong et al. (2018) in ground beef added of $A$. bisporus mushroom (25 to $50 \%$ ). As for the parameter $\mathrm{a}^{*}$ (redness), only treatment G1S1C1 (10\% fat, $0.5 \%$ salt and $0 \%$ mushroom) presented a significant difference in relation to the control (20\% fat, $2.0 \%$ salt and $0 \%$ mushroom). The greater redness intensity of the G1S1C1 treatment is possibly related to the absence of mushrooms and less fat (both light yellow), which, if present, would tend to reduce the red color intensity of the meat. The lower salt content of this sample may have favored the maintenance of the bright red oxymyoglobin, since myoglobin oxidation with the formation of the brown-colored metmyoglobin is directly proportional to the chloride (anion) concentration (Trout, 1990).

No treatment presented a significant difference in the $b^{*}$ coordinate (yellowness) in relation to the control. However, higher mean values were found in the treatments added with mushroom. Accordingly, G1S1C1 (0\% mushroom, 10\% fat) and G3S3C3 (30\% mushroom, 20\% fat) presented the lowest and highest intensity of yellow color, respectively, indicating that fat and mushroom increased the yellowness of the burger. Mattar et al. (2018) and Pil-Nam et al. (2015) found a higher yellow color intensity of meat products manufactured with mushroom powder in the formulation.

In relation to the TBARS data, raw burgers presented lipid oxidation values lower than $0.54 \mathrm{mg} \mathrm{MDA} / \mathrm{kg}$ of sample (Table 3), which is an acceptable level for processed meat products. In fact, TBARS values higher than $2 \mathrm{mg} \mathrm{MDA} / \mathrm{kg}$ meat may induce undesired changes in sensory quality and perception of oxidation by consumers (Trindade et al. 2009).

Burgers presented different TBARS values (Table 3). Among the treatments with 20\% fat, G3S1C2 and G3S3C3 were less oxidized due to the presence of $A$. bisporus mushroom $(0.64 \mathrm{mg} \mathrm{GAE} / \mathrm{g})$ in the formulation. This result clearly shows that phenolic compounds from mushroom act as hydrogen atom donors in burgers. This is confirmed by the result of the formulation $\mathrm{G} 1 \mathrm{~S} 3 \mathrm{C} 2$, which presented the lowest lipid oxidation value and had the incorporation of $15 \%$ mushroom. Similarly, Bao et al. (2008) reported a strong reducing power and high antioxidant activity of mushroom extract, which inhibited the lipid oxidation in beef and fish meats. Treatments with lower amounts of $\mathrm{NaCl}$ (G1S1C1, G2S1C3 and G3S1C2) showed significantly lower TBARS values than G2S3C1 (2\% salt and 15\% fat). This result may be related to the pro-oxidant effect of $\mathrm{NaCl}$ at concentrations of 0.5 to $2.5 \%$, which are normally used in meat products (Rhee, 1999; Rhee \& Ziprin, 2001). Among the possible mechanisms involved in the prooxidant activity of sodium chloride are; salt-induced changes in the cell membrane integrity facilitating the access of oxidizing agents to lipid substrates (Rhee, 1999); iron displacement from macromolecules by the sodium ion (Kanner et al. 1991); inhibition of the activity of antioxidant enzymes, such as catalase, glutathione peroxidase and 
superoxide dismutase (Hernández et al. 2002; Lee et al. 1997). Similar results were found by Sakai et al. (2004), who reported an increase in MDA in beef and pork added with 0 to $2 \% \mathrm{NaCl}$ for 10 days of storage at $1{ }^{\circ} \mathrm{C}$. In addition, among all treatments, G1S3C2 showed the lowest TBARS value, probably because of the presence of the mushroom and the fat reduction.

\section{Texture profile}

In the texture analysis (Table 4), all treatments had a significantly lower hardness than the control, with values ranging from $2628 \mathrm{~g}$ to $9302 \mathrm{~g}$. The addition of mushroom reduced the hardness of the samples, corroborating the results obtained by Süffer et al. (2016) in meatballs. In fact, Aleson-Carbonell et al. (2005) state that the addition of non-meat inputs promotes a dilution of the meat protein and generally reduces the instrumental hardness of the food. These ingredients tend to retain greater amounts of water and fat in the protein matrix, making the food softer. The $\mathrm{NaCl}$ content also modifies the instrumental texture of meat-based products. Treatments with $2 \% \mathrm{NaCl}$ presented higher values of hardness. According to Doyle and Glass (2010), $\mathrm{NaCl}$ content between 1.5 and 2.0\% promotes the solubilization of myofibrillar proteins, increasing water retention and protein binding properties, improving texture and reducing water loss in cooking.

Table 4 shows the effect of the addition of 30\% mushroom on the hardness of the burgers. Specifically, the formulation G2S1C3 (30\% mushroom, $0.5 \% \mathrm{NaCl}$, and $15 \%$ fat) presented a significantly lower hardness than the other formulations. Among the formulations with $15 \%$ mushroom, the hardness of the G1S3C2 presented similar results compared to those of $\mathrm{GS} 2 \mathrm{C} 1$, which does not contain a mushroom and has a fat content commonly used in conventional burgers (20\%).
Regarding the springiness, the burgers were not affected by the reduction of fat and $\mathrm{NaCl}$ nor by the addition of mushrooms. Cohesiveness was significantly affected by these factors. The control and G2S2C2 burgers had the lowest and highest cohesiveness values, respectively. The control is made of more $\mathrm{NaCl}(2.0 \%)$ and more fat (20\%) than G2S2C2 (1.25\% salt and 15\% fat). Youssef and Barbut (2011) reported that cohesivity tends to decrease when the fat content increases, which is confirmed by our results. In another study, Youssef et al. (2011) indicated that high cohesiveness values could be related to high weight loss by cooking, leading to protein concentration and the development of a more cohesive protein matrix.

Treatments G1S2C3, G2S1C3 and G3S1C2 presented significantly lower chewiness compared to the others (Table 4) and this may be associated with their mushroom content. Lower chewiness is related to softer samples which consequently required less work to chew until the sample is swallowed. On the contrary, greater chewing values were found for G1S3C2, G2S3C1, G3S2C1 and control. Except for sample G1S3C2, the other treatments were not manufactured with mushroom and had intermediate or high $\mathrm{NaCl}$ concentrations $(1.5$ and $2.0 \%$, respectively). These observations suggest that samples presented higher concentrations of meat proteins and a sufficient quantity of $\mathrm{NaCl}$ to solubilize and extract them, favoring the adhesion of the pieces and the development of a product with a firmer structure and higher chewing frequency.

\section{Principal component analysis}

To obtain a synthetic view of instrumental measurements, PCA was performed using the Pearson correlation matrix (Fig. 1). The first four dimensions preserved $88.48 \%$ of the

Table 4 Instrumental texture of the ten burger formulations

\begin{tabular}{lllll}
\hline Treatments & Hardness $^{\mathrm{A}}$ & Springiness $^{\mathrm{B}}$ & Cohesiveness $^{\mathrm{B}}$ & Chewiness $^{\mathrm{B}}$ \\
\hline G1S1C1 & $8865 \pm 1321^{\mathrm{b}}$ & $0.845 \pm 0.045^{\mathrm{a}}$ & $0.512 \pm 0.022^{\mathrm{b}}$ & $3865 \pm 868^{\mathrm{bc}}$ \\
G1S2C3 & $4325 \pm 211^{\mathrm{e}}$ & $0.818 \pm 0.059^{\mathrm{a}}$ & $0.538 \pm 0.043^{\mathrm{b}}$ & $1910 \pm 297^{\mathrm{d}}$ \\
G1S3C2 & $9302 \pm 267^{\mathrm{b}}$ & $0.898 \pm 0.041^{\mathrm{a}}$ & $0.577 \pm 0.070^{\mathrm{ab}}$ & $4800 \pm 258^{\mathrm{ab}}$ \\
G2S1C3 & $2628 \pm 270^{\mathrm{f}}$ & $0.816 \pm 0.032^{\mathrm{a}}$ & $0.575 \pm 0.035^{\mathrm{b}}$ & $1242 \pm 218^{\mathrm{d}}$ \\
G2S2C2 & $6207 \pm 439^{\mathrm{cd}}$ & $0.881 \pm 0.007^{\mathrm{a}}$ & $0.701 \pm 0.009^{\mathrm{a}}$ & $3836 \pm 308^{\mathrm{bc}}$ \\
G2S3C1 & $10013 \pm 389^{\mathrm{b}}$ & $0.866 \pm 0.025^{\mathrm{a}}$ & $0.525 \pm 0.053^{\mathrm{b}}$ & $4551 \pm 388^{\mathrm{abc}}$ \\
G3S1C2 & $5560 \pm 151^{\mathrm{de}}$ & $0.799 \pm 0.056^{\mathrm{a}}$ & $0.537 \pm 0.061^{\mathrm{b}}$ & $2375 \pm 154^{\mathrm{d}}$ \\
G3S2C1 & $9895 \pm 23^{\mathrm{b}}$ & $0.887 \pm 0.019^{\mathrm{a}}$ & $0.549 \pm 0.018^{\mathrm{b}}$ & $4820 \pm 175^{\mathrm{ab}}$ \\
G3S3C3 & $7124 \pm 109^{\mathrm{c}}$ & $0.878 \pm 0.011^{\mathrm{a}}$ & $0.571 \pm 0.032^{\mathrm{b}}$ & $3580 \pm 256^{\mathrm{c}}$ \\
Control & $13126 \pm 559^{\mathrm{a}}$ & $0.841 \pm 0.019^{\mathrm{a}}$ & $0.466 \pm 0.050^{\mathrm{b}}$ & $5106 \pm 577^{\mathrm{a}}$
\end{tabular}

Results are means \pm standard deviation. Means followed of letters different (a-f) the same column are significantly different $(P<0,05)$. G1S1C1 $=0 \%$ mushroom, $0,5 \%$ salt, $10 \%$ fat; G1S2C3 = 30\% mushroom, 1,25\% salt, $10 \%$ fat; G1S3C2 = 15\% mushroom, $2 \%$ salt, $10 \%$ fat; G2S1C3=30\% mushroom, 0,5\% salt, $15 \%$ fat; G2S2C2 = 15\% mushroom, 1,25\% salt, 15\% fat; G2S3C1 = 0\% mushroom, 2\% salt, 15\% fat; G3S1C2 = 15\% mushroom, 0,5\% salt, 20\% fat; G3S2C1 = 0\% mushroom $1,25 \%$ salt, $20 \%$ fat; G3S3C3 = 30\% mushroom, $2 \%$ salt, $20 \%$ fat; Control $=0 \%$ mushroom, $2 \%$ salt, $20 \%$ fat. ${ }^{\mathrm{A}}$ (G); ${ }^{\mathrm{B}}$ (adimensional) 

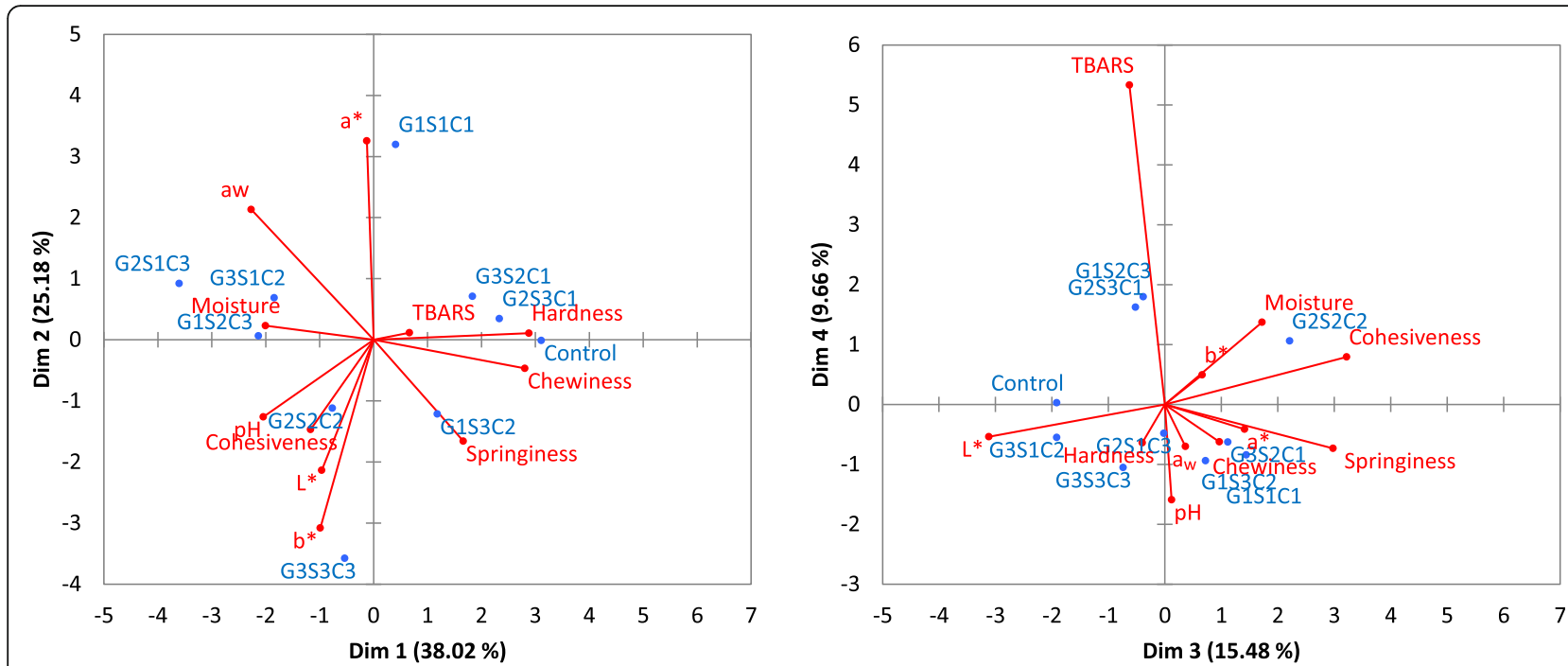

Fig. 1 Principal Component Analysis on the instrumental measures which characterise the formulations of burger beef

original information. In the first two dimensions, samples G1S3C2, G2S2C2, G3S2C1 and the control were characterized by higher hardness, chewiness, springiness, lower $\mathrm{a}_{\mathrm{w}}$ and moisture. This behavior was reported by Gao et al. (2014), who indicated that hardness is inversely correlated to the retention of moisture.

Sample G1S1C1 (0\% mushroom) presented a higher redness while G1S2C3, G2S1C3 and G3S1C2 had a high moisture and water activity due to the presence of the mushroom extract. Finally, samples G2S2C2 and G3S3C3 were characterized by high $\mathrm{pH}$, cohesiveness, $\mathrm{L}^{*}$ and $b^{*}$ values. In the third and fourth dimensions the oxidative stability was better represented, being influenced mainly by the salt and mushroom contents. The TBARS vector was located in the third dimension, where in the positive part the most oxidized samples were found (G1S2C3, G2S2C2 and G2S3C1), in the middle of the map the control sample was found and in the negative part the rest of samples, which showed the lowest level of oxidation. The most oxidized samples had intermediate / low levels of fat, medium / high salt and low / high level of mushrooms. Therefore, low levels of salt and fat are recommended to obtain products with low oxidation.

\section{Sensory analysis}

According to the MAM-CAP (Table 5), the trained panel presented a suitable discriminative capacity, repeatability and agreement. The consensus was studied in detail, being unfolded in the two possible causes: the use of scale and the disagreement pure. The use of scale was significant in 5 of the 10 sensory attributes and, on the other hand, the pure disagreement was observed only for characteristic flavor. For these reasons, 7 assessors received one more training session. Finally, the panel was considered suitable for final evaluation of the samples.

The treatments with mushroom addition (G1S3C2 and G3S3C3) presented similar scores to the control for the attributes "salty", "juicy", "seasoned" and "characteristic flavor". For the "grilled" attribute, samples G1S2C3 and G3S3C3 presented significantly lower values than the control, which may be related to the lower meat protein content. Sample G3S3C3 garnered the lowest score for the "fibrous" attribute, indeed, this formulation had less beef meat and, consequently, less muscle fibers, that is, filaments oriented in the same direction (ABNT, 2017).

Although the burger is a high-fat meat product, the "greasy" attribute had intermediate values $(\sim 5$ on a $9 \mathrm{~cm}$ scale). The treatment G1S3C2 had a similar score compared to the control; however, it has half the amount of fat added, suggesting that the high fiber content of the mushroom was able to minimize the effects of fat reduction. According to Cheung (1997), Furlani (2004), and Pauli (2010) A. bisporus is considered as a good source of fibers $(18.2-20.44 \%)$ with potential as partial fat substitute (Brewer, 2012; Piňero et al. 2008; Zhang et al. 2010).

The treatments G1S3C2 and G3S3C3 were significantly more "succulent" and "soft" than the control. These results suggest that the fibers not only improved the perception of "fatty" but also increased "juiciness", since the mushroom retains the moisture and fat of the beef burgers after cooking.

The attributes "salty", "seasoned", "characteristic flavor", "brittle" and "characteristic aroma" were not affected by the addition of the mushroom in treatments G1S3C2 and G3S3C3 when compared to the control. Mattar (2016) used Shiitake mushroom extract in the development of 
Table 5 MAM-CAP table at 5\% significance for the sensory panel and for the assessors

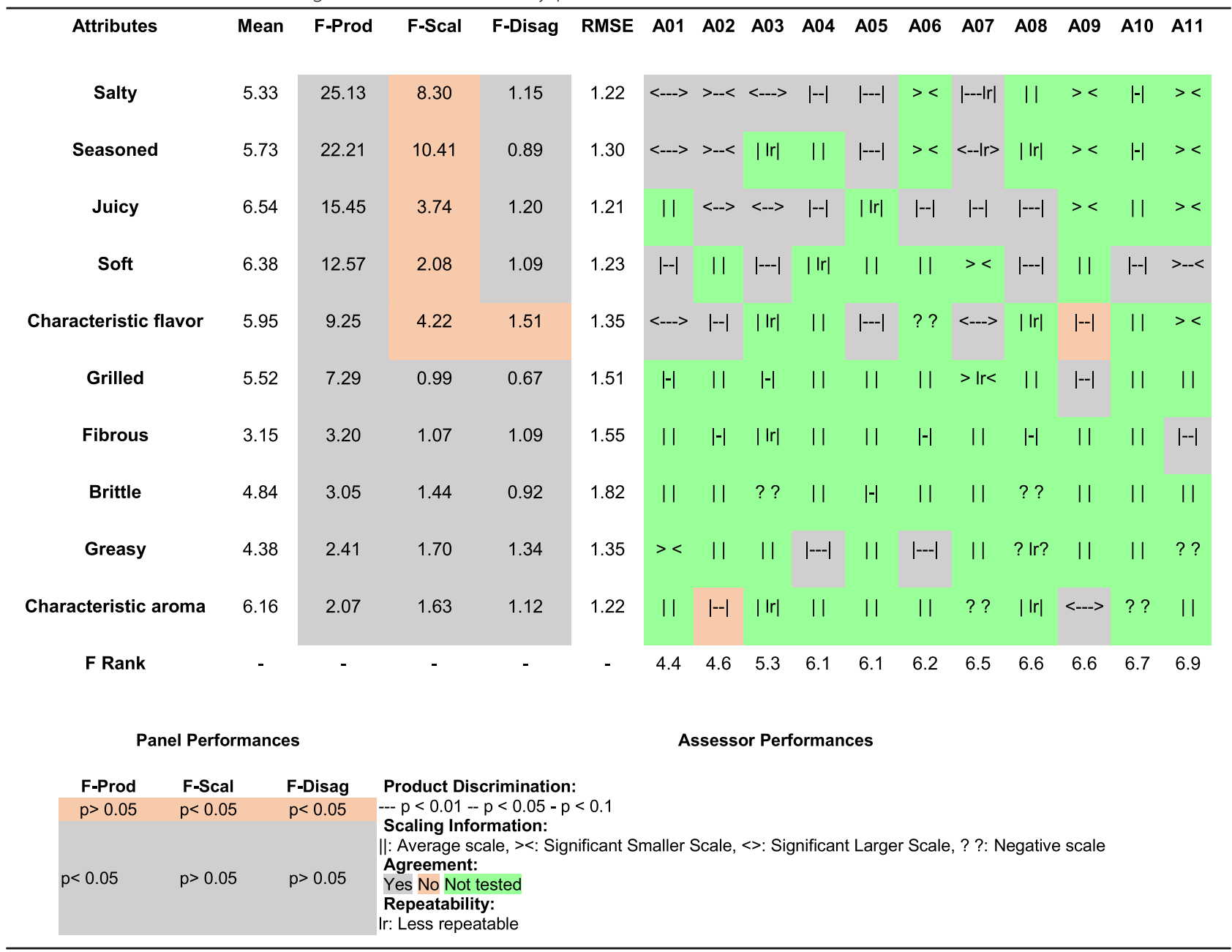

low sodium burgers without modifying the physicochemical and sensory properties of the samples (Table 6).

In the CVA, the first two dimensions retained $92.05 \%$ of the original information (Fig. 2) and the biplot shows high discrimination between samples. The only multivariate similarities were found in the G1S3C2 and G3S3C3 treatments as well as in the control and G2S3C1 formulations. The positioning of the samples within the sensory map reveals that the first canonical variable is associated with the $\mathrm{NaCl}$ content. Samples manufactured with $0.5 \% \mathrm{NaCl}$ are positioned in the negative part of the first variable and are characterized by no sensory attributes. In the positive part of this variable, the burgers containing 1.25 and $2.0 \% \mathrm{NaCl}$ are perceived as "salty", "seasoned", "succulent" and with "characteristic flavor".

On the other hand, the second canonical variable is related to the mushroom content in the formulation. In the positive part of the second canonical variable, the burgers with $0 \%$ of mushroom are positioned and the sensory attributed that describe these samples are "grilled", "fibrous" and "fatty". This clearly occurred because they were manufactured with 100\% beef. In the negative part of this variable, the burgers manufactured with $30 \%$ of mushroom are positioned and are perceived as "brittle", "succulent" and "soft". These sensory terms are associated with the higher water content in the formulations and are associated with the high moisture content and water retention capacity of mushroom. Treatments G1S3C2, G2S2C2 and G3S1C2, which have intermediate concentrations of mushroom, are in the middle of the sensory map, along the first dimension. The "fat" factor was not directly associated with any canonical variable indicating a minor effect on the sensory profile of the product. Therefore, incorporating mushrooms as a partial fat substitute seems the best reformulation strategy while maintaining the sensory and instrumental quality of the product.

\section{Conclusions}

According to the fractional factorial design, the mushroom was the most important factor followed by salt and fat. The incorporation of mushroom did not affect 


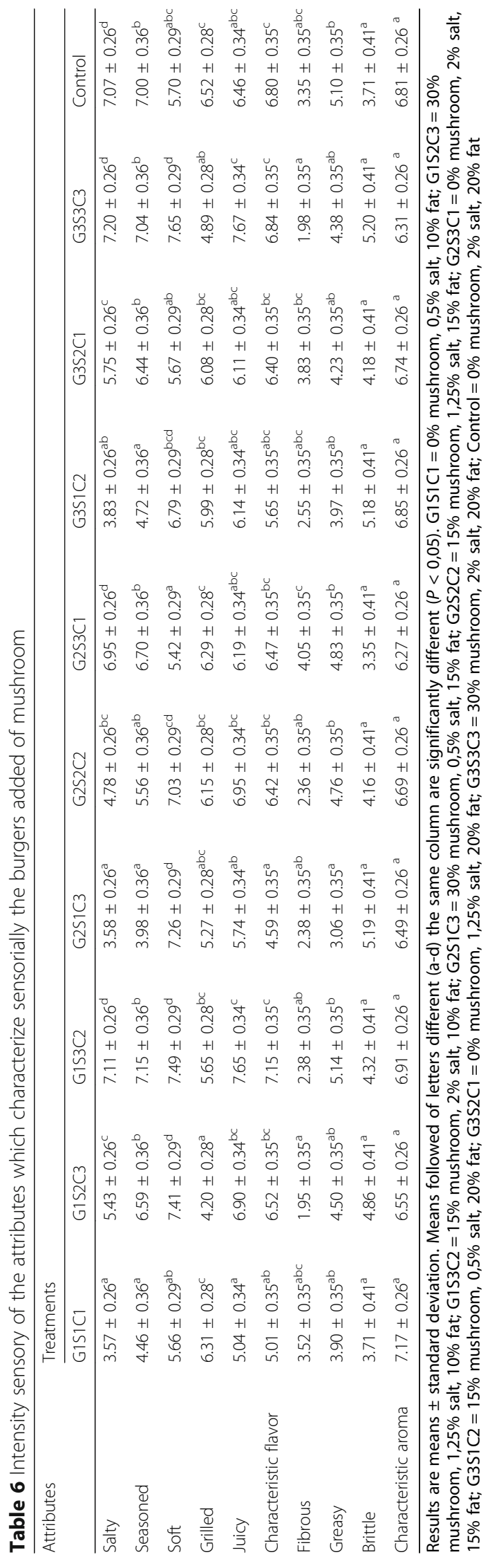




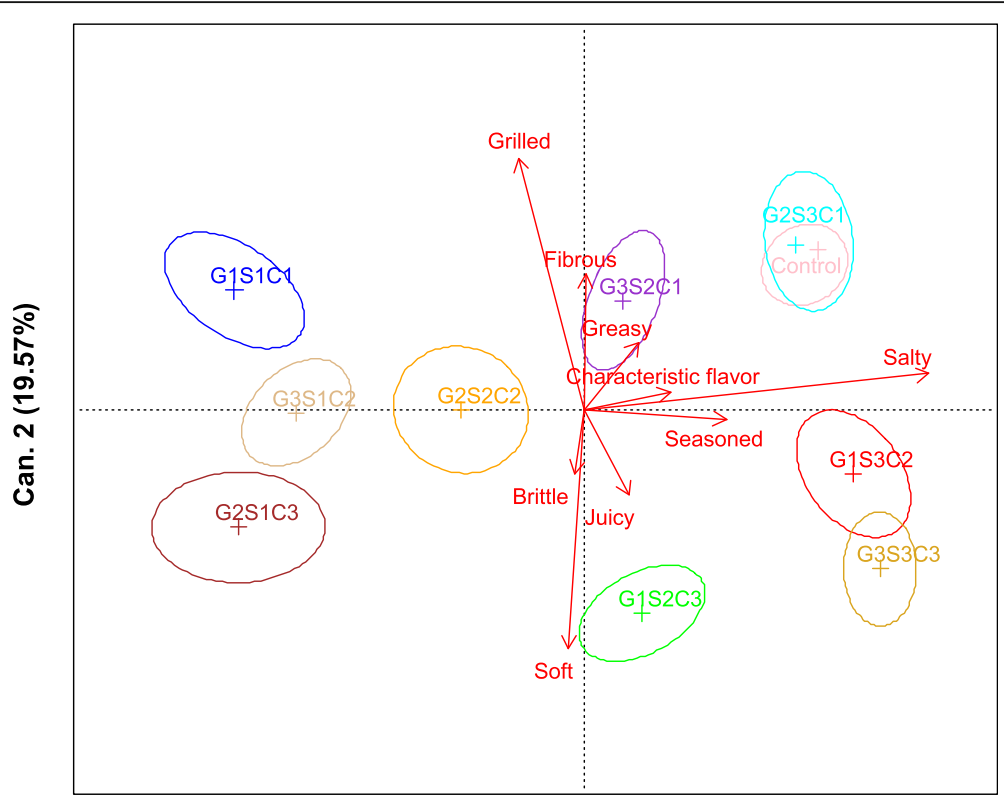

Can. $1(72.48 \%)$

Fig. 2 Canonical Variables Analysis on the matrix of correlation of the attributes evaluated of the 10 burger formulations

the color of the samples compared to the control, but the others instrumental properties were effectively modified, specifically generating softened the burgers. On the other hand, the lowest lipid oxidation rate was observed in the formulation containing the lowest fat content, the intermediate level of mushroom and the highest $\mathrm{NaCl}$ concentration. Mushroom and salt caused the main sensory changes in the samples while the fat content marginally affected the sensory profile. Therefore, using mushrooms as a partial substitute for fat seems the best strategy from sensory and instrumental perspectives. However, more studies must be done to determine the impact of replacing fat with mushrooms on the perception of consumers.

\section{Supplementary information}

Supplementary information accompanies this paper at https://doi.org/10. 1186/s43014-019-0006-3.

Additional file 1: Table S1. Formulations (\%) of the hamburgers developed using the $3^{3-1}$ fractional factorial design. Table S2. Names, definitions, assessment techniques and references used to determine the sensory attributes of burgers.

\section{Acknowledgments}

The authors are grateful to the CAPES (Coordenação de Aperfeiçoamento de Pessoal de Nível Superior, Brazil). Iliani Patinho received the M.Sc. scolarship of the CAPES ( $n^{\circ}$ 1766129). E. Saldaña received the support of the "Consejo Nacional de Ciencia, Tecnología e Innovación Tecnológica - CONCYTEC" from Peru (CIENCIACTIVA programme n 104-2016-FONDECYT) for student scholarships. A. C. de Camargo acknowledges Conicyt (Fondecyt Postdoctorado $n^{\circ}$ 3180432). The authors would also like to thank Zucca mushrooms Company,
VPJ Foods, Ibrac Additives and Condiments and Sealed Air Brasil in São Paulo, Brazil for the donation of inputs.

\section{Authors' contributions}

IP, ES, MMS, ACC and CJCC conceived and designed the study. ES carried out all the statistical analyzes. ACC and APSS contributed to the chemical analysis. TCM and BSM physicochemical and sensory collected the data. IP, ES, MMS, ACC and CJCC wrote the paper. All the authors discussed and approved the final manuscript.

\section{Funding}

The author(s) declare(s) that has been no significant financial support for this work that could have influenced its outcome.

\section{Availability of data and materials}

All data generated or analysed during this study are available from Corresponding author but restrictions apply to the availability of these data, which were used under license for the current study, and so are not publicity available. Data are however available from the authors upon reasonable request and with permission of Corresponding author.

\section{Ethics approval and consent to participate}

Participants signed the Free and Informed Consent Term (TCLE) approved by the Human Research Ethics Committee n. CAAE: 98168118.4 .0000 .5395 where all the information about the study is included.

\section{Consent for publication}

The author (s) declare (s) that the document TCLE was signed by each participant. The data obtained in the research will data be released in an article format, however, the identity of all participants will be kept in secrecy.

\section{Competing interests}

The author(s) declare(s) that they have no competing interests.

\section{Author details}

'Departamento de Agroindústria, Alimentos e Nutrição (LAN), Escola Superior de Agricultura "Luiz de Queiroz" (ESALQ), Universidade de São Paulo (USP), Avenida Pádua Dias, 11, Piracicaba, SP 13418-900, Brazil. ${ }^{2}$ Centro de Ciências da Natureza, Campus Lagoa do Sino, Universidade Federal de São Carlos, 
Rod. Lauri Simões de Barros, Km 12, Buri, SP, Brazil. ${ }^{3}$ Departamento de Ciencias Vegetales, Facultad de Agronomía e Ingeniería Forestal, Pontificia Universidad Católica de Chile, Casilla, 306-22 Santiago, Chile. ${ }^{4}$ Facultad de Ingeniería Agroindustrial, Universidad Nacional de Moquegua (UNAM), Moquegua, Peru.

\section{Received: 22 June 2019 Accepted: 10 September 2019}

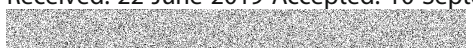

\section{References}

ABNT Associação Brasileira de Normas Técnicas. 2017. (NBR ISO 5492). Sensory analysis - vocabulary. Accessed 28 Oct 2018.

Aiking, H. (2011). Future protein supply. Trends in Food Science \& Technology, 22(2), 112-120. https://doi.org/10.1016/j.tifs.2010.04.005.

Al-Duais, M., Müller, L., Böhm, V., \& Jetschke, G. (2009). Antioxidant capacity and total phenolics of Cyphostemma digitatum before and after processing: Use of different assays. European Food Research and Technology, 228(5), 813-821. https://doi.org/10.1007/s00217-008-0994-8.

Aleson-Carbonell, L., Fernández-López, J., Pérez-Alvarez, J. A., \& Kuri, V. (2005). Characteristics of beef burger as influenced by various types of lemon albedo. Innovative Food Science and Emerging Technologies, 6(2), 247-255. https://doi.org/10.1016/j.jset.2005.01.002

Almeida, M. A., Villanueva, N. D. M., Pinto, J. S. S., Saldaña, E., \& Contreras-Castillo, C. J. (2016). Sensory and physicochemical characteristics of low sodium salami. Scientia Agricola, 73(4). https://doi.org/10.1590/0103-9016-2015-0096.

Alnoumani, H., Ataman, Z. A. \& Were, L. (2017). Lipid and protein antioxidant capacity of dried Agaricus bisporus in salted cooked ground beef. Meat Science, 129, 9-19. https://doi.org/10.1016/..meatsci.2017.02.010.

ANPC Associação Nacional dos Produtores de Cogumelos. (2013). Cogumelos https://www.anpccogumelos.org/cogumelos. Accessed 11 Feb 2019.

ANVISA Agência Nacional de Vigilância Sanitária. (2012). Teor de sódio dos alimentos processados http://portal.anvisa.gov.br/documents/33916/388729/ Informe+t\%C3\%A9cnico+n\%C2\%BA+50\%2C+de+2012/1bd1f41c-4a57-42aa9f00-0f92c27b818f. Accessed 28 Jan 2019.

AOAC Association of Official Analytical Chemists. (1996). Official method 956.01 Ch. 3 (16th ed.p. 10A) Accessed 15 May 2018.

AOAC Association of Official Analytical Chemists. (2000). Official methods of analysis of the AOAC (17th ed.) Accessed 17 May 2018

AOCS American Oil Chemists' Society, (1990). 2-Thiobarbituric acid value, direct method. Cd 19-90 (7th ed.). Champaign: Official methods and recommended practices of the American Oil Chemists' Society Accessed 10 May 2018.

Araújo, B. S. (2017). Processamento e caracterização física e química de hambúrqueres formulados com pectina do maracujá amarelo Dissertação (Mestrado) - Universidade Estadual do Sudoeste da Bahia. http://www2.uesb. br/ppg/ppgecal/wp-content/uploads/2017/05/BRENDA-SOUZA-DE-ARA\%C3\% 9AJO.pdf. Accessed 2 Nov 2018

Bach, F. (2017). Avaliação do potencial nutricional, antioxidante e antibacteriano de cogumelos comestíveis Tese (Doutorado) - Universidade Federal do Paraná https://acervodigital.ufpr.br/handle/1884/51245. Accessed 11 Jan 2019.

Bach, F., Zielinski, A. A. F., Helm, C. V., Maciel, G. M., Pedro, A. C., Stafussa, A. P. Ávila, S., \& Haminiuk, C. W. I. (2019). Bio compounds of edible mushrooms: In vitro antioxidant and antimicrobial activities. LWT - Food Science and Technology, 107, 214-220. https://doi.org/10.1016/j.lwt.2019.03.017.

Bao, H. N. D. Ushio, H. \& Ohshima, T. (2008). Antioxidative activity and antidiscoloration efficacy of ergothioneine in mushroom (Flammulina velutipes) extract added to beef and fish meats. Journal of Agricultural and Food Chemistry, 56(21), 10032-10040. https://doi.org/10.1021/ff8017063.

Barros, L., Falcão, S., Baptista, P., Freire, C., Vilas-Boas, M., \& Ferreira, I. C. F. R. (2008). Antioxidant activity of Agaricus sp. mushrooms by chemical, biochemical and electrochemical assays. Food Chemistry, 111(1), 61-66. https://doi.org/10.1016/j.foodchem.2008.03.033

Brewer, M. S. (2012). Reducing the fat content in ground beef without sacrificing quality: A review. Meat Science, 91(4), 385-395. https://doi.org/10.1016/j. meatsci.2012.02.024

Brockhoff, P. B., Schlich, P., \& Skovgaard, I. B. (2015). Taking individual scaling differences into account by analyzing profile data with the mixed assessor model. Food Quality and Preference, 39, 156-166. https://doi.org/10.1016/j foodqual.2014.07.005.

Cha, M. H., Heo, J. Y., Lee, C., Martin Lo, Y., \& Moon, B. (2014). Quality and sensory characterization of white jellymushroom (tremella fuciformis) as a meat substitutein pork patty formulation. Journal of Food Processing and Preservation, 38(3), 1018-1023. https://doi.org/10.1111/jfpp.12058.

Chandrasekara, A., \& Shahidi, F. (2011). Determination of antioxidant activity in free and hydrolyzed fractions of millet grains and characterization of their phenolic profiles by HPLC-DAD-ESI-MS ${ }^{n}$. Journal of Functional Foods, 3(3), 144-158. https://doi.org/10.1016/j.jf.2011.03.007.

Chang, I., \& Watts, B. M. (1950). Some effects of salt and moisture on rancidity in fats. Journal of Food Science, 15(4), 313-321. https://doi.org/10.1111/j.13652621.1950.tb16478.x.

Chang, S. T. (1999). World production of cultivated edible and medicinal mushrooms in 1997 with emphasis on Lentinus edodes (Berk.) sing. In China. International Journal of Medicinal Mushrooms, 1(4), 291-300. https://doi.org/ 10.1615/IntJMedMushr.v1.i4.10.

Chang, S. T. (2008). Overview of mushroom cultivation and utilization as functional foods. In Mushrooms as functional foods. Chapter 1. New Jersey: Wiley. https://doi.org/10.1002/9780470367285.ch1

Cheung, P. C. K. (1997). Dietary fiber content and composition of some edible fungi determined by two methods of analysis. Journal of the Science of Food and Agriculture, 73(2), 255-260. https://doi.org/10.1002/(SICI)10970010(199702)73:2<255::AID-JSFA723>3.0.CO;2-U.

Choe, J., Lee, J., Jo, K., Jo, C., Song, M., \& Jung, S. (2018). Application of winter mushroom powder as an alternative to phosphates in emulsion-type sausages. Meat Science, 143, 114-118. https://doi.org/10.1016/j.meatsci.2018. 04.038

de Camargo, A. C., Regitano-d'Arce, M. A. B., Biasoto, A. C. T., \& Shahidi, F. (2016). Enzyme-assisted extraction of phenolics from winemaking by-products: Antioxidant potential and inhibition of alpha-glucosidase and lipase activities. Food Chemistry, 212, 395-402. https://doi.org/10.1016/j.foodchem.2016.05.047.

de Camargo, A. C., Regitano-d'Arce, M. A. B., Rasera, G. B., Canniatti-Brazaca, S. G., do Prado Silva, L., Alvarenga, V. O., Sant'Ana, A. S., \& Shahidi, F. (2017). Phenolic acids and flavonoids of peanut by-products: Antioxidant capacity and antimicrobial effects. Food Chemistry, 237, 538-544. https://doi.org/10. 1016/j.foodchem.2017.05.046.

de Camargo, A. C., Regitano-d'Arce, M. A. B., \& Shahidi, F. (2017). Phenolic profile of peanut by-products: Antioxidant potential and inhibition of alphaglucosidase and lipase activities. Journal of the American Oil Chemists' Society, 94(7), 959-971. https://doi.org/10.1007/s11746-017-2996-9.

de Camargo, A. C. \& Schwember, A. R. (2019). Phenolic-driven sensory changes in functional foods. Journal of Food Bioactives, 5, 6-7. https://doi.org/10 31665/JFB.2019.5173.

de Camargo, A. C., Schwember, A. R., Parada, R., Garcia, S., Júnior, M. R. M., Franchin, M., Regitano-d'Arce, M. A. B., \& Shahidi, F. (2018). Opinion on the hurdles and potential health benefits in value-added use of plant food processing by-products as sources of phenolic compounds. International Journal of Molecular Sciences, 19(11), 1-47. https://doi.org/10.3390/ ijms19113498.

de Jesus, J. P. F. (2015). Desenvolvimento de hambúrguer vegetariano a base de cogumelos do gênero Pleurotus: composição nutricional, propriedades sensoriais e viabilidade econômica Monografia (Física Médica) - Universidade Estadual Paulista. https://intranet.ibb.unesp.br/comissoes/anexos/2/PROJETO_Joao_ Paulo_Furlan_de_Jesus_carta_de_anuencia.pdf. Accessed 19 Nov 2018.

Doyle, M. E., \& Glass, K. A. (2010). Sodium reduction and its effect on food safety, food quality, and human health. Comprehensive Reviews in Food Science and Food Safety, 9, 44-56. https://doi.org/10.1111/j.1541-4337.2009.00096.x.

Dubost, N. J., Ou, B., \& Beelman, R. B. (2007). Quantification of polyphenols and ergothioneine in cultivated mushrooms and correlation to total antioxidant capacity. Food Chemistry, 105, 727-735. https://doi.org/10.1016/j.foodchem. 2007.01.030

Furlani, R. P. Z. (2004). Valor nutricional de cogumelos cultivados no Brasil Tese (Doutorado) - Universidade Estadual de Campinas. http://repositorio unicamp.br/bitstream/REPOSIP/254295/1/Furlani_ReginaPradoZanes_D.pdf. Accessed 18 Nov 2018

Gao, X., Zhang, W., \& Zhou, G. (2014). Effects of glutinous rice flour on the physiochemical and sensory qualities of ground pork patties. LWT- Food Science and Technology, 58(1), 135-141. https://doi.org/10.1016/j.lwt.2014. 02.044 .

Gąsecka, M., Magdziak, Z., Siwulski, M., \& Mleczek, M. (2018). Profile of phenolic and organic acids, antioxidant properties and ergosterol content in cultivated and wild growing species of Agaricus. European Food Research and Technology, 244(2), 259-268 https://link.springer.com/article/10.1007/s00217017-2952-9. 
Granato, D., Shahidi, F., Wrolstad, R., Kilmartin, P., Melton, L. D., Hidalgo, F. J., Miyashita, K., van Camp, J., Alasalvar, C., Ismail, A. B., Elmore, S., Birch, G. G. Charalampopoulos, D., Astley, S. B., Pegg, R., Zhou, P., \& Finglas, P. (2018). Antioxidant activity, total phenolics and flavonoids contents: Should we ban in vitro screening methods? Food Chemistry, 264, 471-475. https://doi.org/10. 1016/j.foodchem.2018.04.012.

Hernández, P., Park, D., \& Rhee, K. S. (2002). Chloride salt type/ionic strength, muscle site and refrigeration effects on antioxidant enzymes and lipid oxidation in pork. Meat Science, 61(4), 405-410. https://doi.org/10.1016/ S0309-1740(01)00212-1.

Huber, E. (2012). Desenvolvimento de produtos cárneos reestruturados de frango (hambúrguer e empanado) com adição de fibras vegetais Como substitutos totais de gordura Tese (Doutorado) - Universidade Federal de Santa Catarina. https:// repositorio.ufsc.br/xmlui/handle/123456789/100599. Accessed 2 Nov 2018.

ITAL Instituto de Tecnologia de Alimentos. (2010). Brasil food trends 2020 http:// www.brasilfoodtrends.com.br. Accessed 9 Nov 2018.

Kanner, J, Harel, S, Jaffe, R (1991). Lipid peroxidation of muscle food as affected by $\mathrm{NaCl}$. Journal of Agricultural and Food Chemistry, 39 (6), 1017-1021 (1991). https://doi.org/10.1021/jf00006a002

Kendall, C. W. C., Esfahani, A., \& Jenkins, D. J. A. (2010). The link between dietary fibre and human health. Food Hydrocolloids, 24(1), 42-48. https://doi.org/10. 1016/j.foodhyd.2009.08.002.

Kim, D. O., Jeong, S. W., \& Lee, C. Y. (2003). Antioxidant capacity of phenolic phytochemicals from various cultivars of plums. Food Chemistry, 81(3), $321-$ 326. https://doi.org/10.1016/S0308-8146(02)00423-5.

Kita, A., Bąkowska-Barczak, A., Hamouz, K., Kułakowska, K., \& Lisińska, G. (2013). The effect of frying on anthocyanin stability and antioxidant activity of crisps from redand purple-fleshed potatoes (Solanum tuberosum L.). Journal of Food Composition and Analysis, 32(2), 169-175. https://doi.org/10.1016/j.ffca. 2013.09.006.

Lawless, H. T., \& Heymann, H. (2010). Sensory evaluation of food: Principles and practices. New York: Springer.

Lee, S. K., Mei, L., \& Decker, E. A. (1997). Influence of sodium chloride on antioxidant enzyme activity and lipid oxidation in frozen ground pork. Meat Science, 46(4), 349-355. https://doi.org/10.1016/S0309-1740(97)00029-6.

Lemos, F. M. R. (2009). Elaboração e caracterização de produto análogo a hambúrguer de cogumelo Agaricus brasiliensis Dissertação (Mestrado) Universidade Federal do Paraná. http://hdl.handle.net/1884/20679. Accessed 19 Sept 2018

Liu, J., Jia, L., Kan, J., \& Jin, C. (2013). In vitro and in vivo antioxidant activity of ethanolic extract of white button mushroom (Agaricus bisporus). Food and Chemical Toxicology, 51, 310-316. https://doi.org/10.1016/j.fct.2012.10.014.

Manzi, P., Aguzzi, A., \& Pizzoferrato, L. (2001). Nutritional value of mushrooms widely consumed in Italy. Food Chemistry, 73(3), 321-325. https://doi.org/10. 1016/S0308-8146(00)00304-6.

Mattar, T. V. (2016). Aplicação de extrato de cogumelo shiitake no desenvolvimento de hambúrguer com teor reduzido de cloreto de sódio Dissertação (Mestrado) Universidade Federal de Lavras. http://repositorio.ufla.br/jspui/bitstream/1/1101 0/2/DISSERTA\%C3\%87\%C3\%830_Aplica\%C3\%A7\%C3\%A30\%20de\%2 0extrato\%20de\%20cogumelo\%20shiitake\%20no\%20desenvolvimento\%20\%2 0de\%20hamb\%C3\%BArguer\%20com\%20teor\%20reduzido\%20de\%20cloreto\%2 0de\%20s\%C3\%B3dio.pdf. Accessed 2 Nov 2018.

Mattar, T. V., Gonçalves, C. S., Pereira, R. C., Faria, M. A., Souza, V. R., \& Carneiro, J. D. S. (2018). A shiitake mushroom extract as a viable alternative to $\mathrm{NaCl}$ for a reduction in sodium in beef burgers: A sensory perspective. British Food Journal, 120(6), 1366-1380. https://doi.org/10.1108/BFJ-05-2017-0265.

Mattila, P., Könkö, K., Eurola, M., Pihlava, J. M., Astola, J., Vahteristo, L., Hietaniemi, V., Kumpulainen, J., Valtonen, M., \& Piironen, V. (2001). Contents of vitamins, mineral elements, and some phenolic compounds in cultivated mushrooms. Journal of Agricultural and Food Chemistry, 49, 2343-2348. https://doi.org/10. 1021/jf001525d.

Melo, P. S., Massarioli, A. P., Denny, C., dos Santos, L. F., Franchin, M., Pereira, G. E., Vieira, T. M., Rosalen, P. L., \& de Alencar, S. M. (2015). Winery by-products: Extraction optimization, phenolic composition and cytotoxic evaluation to act as a new source of scavenging of reactive oxygen species. Food Chemistry, 181, 160-169. https://doi.org/10.1016/j.foodchem.2015.02.087.

Merlo, T. C., Soletti, I., Saldaña, E., Menegali, B. S., Martins, M. M., Teixeira, A. C. B., Harada-Padermo, S. S., Dargelio, M. D. B., \& Contreras-Castillo, C. J. (2018). Measuring dynamics of emotions evoked by the packaging colour of hamburgers 1 using temporal dominance of emotions (TDE). Food Research InternationalAvailable online. https://doi.org/10.1016/j.foodres.2018.08.007.
Muller, L., Gnoyke, S., Popken, A. M., \& Bohm, V. (2010). Antioxidant capacity and related parameters of different fruit formulations. $L W T$ - Food Science and Technology, 43(6), 992-999. https://doi.org/10.1016/j.lwt.2010.02.004.

$\mathrm{Ng}$, Z. X., \& Tan, W. C. J. (2017). Impact of optimised cooking on the antioxidant activity in edible mushrooms. Journal Food Sciencia and Technologic, 54(12), 4100-4111. https://doi.org/10.1007/s13197-017-2885-0.

Palacios, I., Lozano, M., Moro, C., D’Arrigo, M., Rostagno, M. A., Martínez, J. A., García-Lafuente, A., Guillamón, E., \& Villares, A. (2011). Antioxidant properties of phenolic compounds occurring in edible mushrooms. Food Chemistry, 128, 674-678. https://doi.org/10.1016/j.foodchem.2011.03.085.

Pauli, A. P. (2010). Avaliação da composição química, compostos bioativos e atividade antioxidante em cogumelos comestiveis Dissertação (Mestrado) Universidade Estadual Paulista "Júlio de Mesquita Filho". https://www2.fcfar. unesp.br/Home/Pos-graduacao/AlimentoseNutricao/PriscilaAbackerliME.pdf. Accessed 25 Jan 2019.

Peltier, C., Brockhoff, P. B., Visalli, M., \& Schlich, P. (2014). The MAM-CAP table: A new tool for monitoring panel performances. Food Quality and Preference, 32, 24-27. https://doi.org/10.1016/j.foodqual.2013.07.004.

Peltier, C., Visalli, M., \& Schlich, P. (2018). Enhancing canonical variate analysis by taking the scaling effect into account. Food Quality and Preference, 64, 88-93. https://doi.org/10.1016/j.foodqual.2017.10.019.

Perera, N., Ambigaipalan, P., \& Shahidi, F. (2018). Epigallocatechin gallate (EGCG) esters with different chain lengths fatty acids and their antioxidant activity in food and biological systems. Journal of Food Bioactives, 1, 124-133 10.xxxxx/ JFB.2018.00003.

Phat, C., Moon, B., \& Lee, C. (2016). Evaluation of umami taste in mushroom extracts by chemical analysis, sensory evaluation, and an electronic tongue system. Food Chemistry, 192(1), 1068-1077. https://doi.org/10.1016/j. foodchem.2015.07.113.

Pil-Nam, S., Park, K. M., Kang, G. H., Cho, S. H., Park, B. Y., \& Van-Ba, H. (2015). The impact of addition of shiitake on quality characteristics of frankfurter during refrigerated storage. LWT - Food Science and Technology, 62(1), 62-68. https:// doi.org/10.1016/j.lwt.2015.01.032.

Piňero, M. P., Parra, K., Huerta-Leidenz, N., Moreno, L. A., Ferrer, M., Araújo, S. \& Barboza, Y. (2008). Effect of oat's soluble fibre ( $\beta$-glucan) as a fat replacer on physical, chemical, microbiological and sensory properties of low-fat beef patties. Meat Science, 80(3), 675-680. https://doi.org/10.1016/ j.meatsci.2008.03.006.

Ramos, M., Burgos, N., Barnard, A., Evans, G., Preece, J., Graz, M., Ruthes, A. C., Jiménez-Quero, A., Martínez-Abad, A., Vilaplana, F., Ngoc, L. P., Brouwer, A., Van der Burg, B., Garrigós, M. C., \& Jiménez, A. (2019). Agaricus bisporus and its by-products as a source of valuable extracts and bioactive compounds. Food Chemistry, 292, 176-187. https://doi.org/10.1016/j.foodchem.2019.04.035.

Reis, F. S., Martins, A., Barros, L., \& Ferreira, I. C. F. R. (2012). Antioxidant properties and phenolic profile of the most widely appreciated cultivated mushrooms: A comparative study between in vivo and in vitro samples. Food and Chemical Toxicology, 50(5), 1201-1207. https:// doi.org/10.1016/j.fct.2012.02.013.

Reis, F. S., Martins, A., Vasconcelos, M. H., Morales, P., \& Ferreira, I. C. F. R. (2017). Functional foods based on extracts or compounds derived from mushrooms. Trends in Food Science \& Technology, 66, 48-62. https://doi.org/10.1016/j.tifs. 2017.05.010.

Rhee, K. S. (1999). Storage stability of meat products as affected by organic and inorganic additives and functional ingredients. In Xiong et al. (Eds.), Quality attributes of muscle foods (pp. 95-113). New York: Plenum Publishers.

Rhee, K. S., \& Ziprin, Y. A. (2001). Pro-oxidative effects of $\mathrm{NaCl}$ in microbial growth-controlled and uncontrolled beef and chicken. Meat Science, 57(1), 105-112. https://doi.org/10.1016/S0309-1740(00)00083-8.

Ribeiro, J. S., Santos, M. J. M. C., Silva, L. K. R., Pereira, L. C. L., Santos, I. A., Lannes, S. C. S., \& Silva, M. V. (2019). Natural antioxidants used in meat products: A brief review. Meat Science, 148, 181-188. https://doi.org/10.1016/j.meatsci. 2018.10.016

Rios-Mera, J. D., Saldaña, E., Cruzado-Bravo, M. L. M., Patinho, I., Selani, M. M., Valentin, D., \& Contreras-Castillo, C. J. (2019). Reducing the sodium content without modifying the quality of beef burgers by adding micronized salt. Food Research International, 121, 288-295. https://doi.org/10.1016/j.foodres. 2019.03.044.

Sakai, T., Munasinghe, D. M. S., Kashimura, M., Sugamoto, K., \& Kawahara, S. (2004). Effect of $\mathrm{NaCl}$ on lipid peroxidation-derived aldehyde, 4-hydroxy-2-nonenal formation in minced pork and beef. Meat Science, 66(4), 789-792. https://doi. org/10.1016/S0309-1740(03)00138-4. 
Saldaña, E., Behrens, J. H., Serrano, J. S., Ribeiro, F., Almeida, M. A., \& ContrerasCastillo, C. J. (2015). Microstructure, texture profile and descriptive analysis of texture for traditional and light mortadella. Food Structure, 6, 13-20. https:// doi.org/10.1016/j.foostr.2015.09.001.

Saldaña, E., Garcia, A. O., Selani, M. M., Haguiwara, M. M. H., Almeida, M. A., Siche, R., \& Contreras-Castillo, C. J. (2018). A sensometric approach to the development of mortadella with healthier fats. Meat Science, 137, 176-190. https://doi.org/10.1016/j.meatsci.2017.11.027.

Saldaña, E., Saldarriaga, L., Cabrera, J., Behrens, J. H., Selani, M. M., Mera, J. R., \& Contreras-Castillo, C. J. (2018). Descriptive and hedonic sensory perception of Brazilian consumers for smoked bacon. Meat Science, 147, 60-69. https://doi. org/10.1016/j.meatsci.2018.08.023.

Sánchez, C. (2010). Cultivation of Pleurotus ostreatus and other edible mushrooms. Applied Microbiology and Biotechnology, 85(5), 1321-1337. https://doi.org/10.1007/s00253-009-2343-7.

Sánchez, C. (2017). Reactive oxygen species and antioxidant properties from mushrooms. Synthetic and Systems Biotechnology, 2(1), 13-22. https://doi.org/ 10.1016/j.synbio.2016.12.001

Schlich, P. (2007). CAP: Une méthode et un outil de contrôle rapide et synthétique des performances des sujets en évaluation sensorielle descriptive. In 5èmes Journées Agro-industries et Méthodes Statistiques, Versailles, 8, 1-10.

Selani, M. M., Contreras-Castillo, C. J., Shirahigue, L. D., Gallo, C. R., Plata-Oviedo, M., \& Villanueva, N. D. M. (2011). Wine industry residues extracts as natural antioxidants in raw and cooked chicken meat during frozen storage. Meat Science, 88(3), 397-403. https://doi.org/10.1016/j.meatsci.2011.01.017.

Selani, M. M., Shirado, G. A. N., Margiotta, G. B., Saldaña, E., Spada, F. P., Piedade, S. M. S., Contreras-Castillo, C. J., \& Canniatti-Brazaca, S. G. (2016). Effects of pineapple byproduct and canola oil as fat replacers on physicochemical and sensory qualities of low-fat beef burger. Meat Science, 112, 69-76. https://doi. org/10.1016/j.meatsci.2015.10.020.

Shahidi, F., \& Hossain, A. (2018). Bioactives in spices, and spice oleoresins: Phytochemicals and their beneficial effects in food preservation and health promotion. Journal of Food Bioactives, 3, 8-75. https://doi.org/10.31665/JFB.2018.3149.

Shahidi, F., \& Peng, H. (2018). Bioaccessibility and bioavailability of phenolic compounds. Journal of Food Bioactives, 4, 11-68. https://doi.org/10.31665/JFB. 2018.4162.

Shahidi, F., Varatharajan, V., Oh, W. Y., \& Peng, H. (2019). Phenolic compounds in Agri-food by-products, their bioavailability and health effects. Journal of Food Bioactives, 5, 57-119. https://doi.org/10.31665/JFB.2019.5178.

Silva, C. P., Soares-Freitas, R. A. M., Sampaio, G. R., de Camargo, A. C., \& Torres, E. A. F. S. (2019). Guarana as a source of bioactive compounds. Journal of Food Bioactives, 6, 1-5. https://doi.org/10.31665/JFB.2019.6182.

Srinivasan, S., \& Xiong, Y. L. (1996). Sodium chloridemediated lipid oxidation in beef heart surimi-like material. Journal of Agricultural and Food Chemistry, 44, 1697-1703. https://doi.org/10.1021/jf950748e.

Steinfeld, H., Gerber, P., Wassenaar, T. D., Castel, V., \& de Haan, C. (2006). Livestock's long shadow: Environmental issues and options. Rome: Food \& Agriculture Org FAO 978-92-5-195571-7.

Süffer, O., Bozok, F., \& Demir, H. (2016). Usage of edible mushrooms in various food products. Food Science and Technology, 4(3), 144-149. https://doi.org/10. 24925/turjaf.v4i3.144-149.599.

Tom, N., Alnoumani, H. A., \& Were, N. (2018). Interactions between mushroom powder, sodium chloride, and bovine proteins and their effects on lipid oxidation products and consumer acceptability. LWT- Food Science and Technology, 98, 219-224. https://doi.org/10.1016/j.lwt.2018.08.044.

Trindade, R. A., Mancini-Filho, J., \& Villavicencio, A. L. C. H. (2009). Effects of natural antioxidants on the lipid profile of eléctron beam-irradiated beef burgers. European Journal of Lipid Science and Technology, 111, 1161-1168. https://doi. org/10.1002/ejlt.200900146.

Trout, G. R. (1990). The rate of metmyoglobin formation in beef, pork, and Turkey meat as influenced by $\mathrm{pH}$, sodium chloride, and sodium tripolyphosphate. Meat Science, 28(3), 203-210. https://doi.org/10.1016/0309-1740(90)90004-P.

Tuorila, H., \& Monteleone, E. (2009). Sensory food science in the changing society: Opportunities, needs, and challenges. Trends in Food Science and Technology, 20(2), 54-62. https://doi.org/10.1016/j.tifs.2008.10.007.

Wan Rosli, W. I., \& Solihah, M. A. (2012). Effect on the addition of Pleurotus sajorcaju (PSC) on physical and sensorial properties of beef patty. Food Research International, 19(3), 993-999.

WHO World Health Organization. (2018). Noncommunicable diseases country profiles 2018 https://www.who.int/nmh/publications/ncd-pro-files-2018/en/. Accessed 24 June 2019.
Wong, K. M. (2017). Investigating the utilization of mushrooms in beef-based products for improved health (Master's) Thesis - University of Massachusetts Amherst. https://scholarworks.umass.edu/masters_theses_2/487/. Accessed 30 Nov 2018.

Wong, K. M., Corradini, M. G., Autio, W., \& Kinchla, A. J. (2018). Sodium reduction strategies through use of meat extenders (white button mushrooms vs. textured soy) in beef patties. Food Science \& Nutrition, 1-13. https://doi.org/ $10.1002 / f \operatorname{sn} 3.824$

Youssef, M. K., \& Barbut, S. (2011). Fat reduction in comminuted meat productseffects of beef fat, regular and pre-emulsified canola oil. Meat Science, 87(4), 356-360. https://doi.org/10.1016/j.meatsci.2010.11.011.

Youssef, M. K., Barbut, S., \& Smith, A. (2011). Effects of pre-emulsifying fat/oil on meat batter stability, texture and microstructure. International Journal of Food Science \& Technology, 46, 1216-1224. https://doi.org/10.1111/j.1365-2621. 2011.02607.x.

Zhang, W., Xiao, S., Samaraweera, H., Lee, E. J., \& Du, A. (2010). Improving functional value of meat products. Meat Science, 86(1), 15-31. https://doi.org/ 10.1016/j.meatsci.2010.04.018.

\section{Publisher's Note}

Springer Nature remains neutral with regard to jurisdictional claims in published maps and institutional affiliations.
Ready to submit your research? Choose BMC and benefit from:

- fast, convenient online submission

- thorough peer review by experienced researchers in your field

- rapid publication on acceptance

- support for research data, including large and complex data types

- gold Open Access which fosters wider collaboration and increased citations

- maximum visibility for your research: over $100 \mathrm{M}$ website views per year

At BMC, research is always in progress.

Learn more biomedcentral.com/submissions 